UDK 78(497.4) Ramovš P.

\author{
Ivan Klemenčič
}

Znanstvenoraziskovalni center SAZU, Ljubljana

Scientific Research Centre of the Slovenian Academy of Sciences and Arts

\title{
Zvočni svet Primoža Ramovša (1921-1999)
}

Stoletja glasbenega razvoja nas potrjujejo v misli, da nova in napredna kompozicijska usmerjenost ni ovira za priznanje živečega skladatelja, čeprav vemo, da čas nekaterih prihaja po smrti. Zahteve teh drugih in seveda redkejših so lahko nesprejemljive zaradi svoje eksperimentalnosti ali so pač v temeljnem razkoraku s pojmovanjem glasbe kot umetnosti, s prihajajočimi vrednotami pomenijo napad na tradicionalne vrednote. Ob tem nepomembna ni niti razvitost glasbenega okolja, čeprav tudi ta v najboljšem primeru ne more preprečiti ekscesnih zavrnitev novega $\mathrm{v}$ imenu starega. Ko govorimo o slovenski zgodovinski avantgardi, vemo, da sta bila prodora Marija Kogoja v dvajsetih in Slavka Osterca $v$ tridesetih letih težavna in brez dokončnega priznanja, ${ }^{1}$ pri prvem zaradi zahtev novega poduhovljenega izraza, pri drugem zaradi njegovega ekspresivnega stopnjevanja do atonalne abstrakcije. Avantgardna generacija v šestdesetih letih je lahko izhajala iz že doseženega, čeprav premalo poznanega in uveljavljenega, nekateri njeni skladatelji pa so že prejeli priznanja $\mathrm{v}$ predmodernistični fazi. Točneje povedano so po drugi svetovni vojni $\mathrm{v}$ času komunističnega totalitarizma in umetnosti socialističnega realizma predvojno avantgardo začeli znova odkrivati, kar pomeni, da se je začela uveljavljati vzporedno ali ne dosti pred prihajajočo povojno in je laže vstopila v slovensko zavest kot stara-nova vrednota. Za desetletje starejšega od svojih tedanjih kolegov, za Primoža Ramovša (20. 3. 1921-10. 1. 1999) vsekakor lahko rečemo, da si je že kot avantgardist pridobil sloves ene osrednjih in vodilnih skladateljskih osebnosti svojega časa na Slovenskem, čeprav sprva le v ožjih strokovnih krogih. Četudi je dosežke obeh zgodovinskih avantgard radikaliziral, se je že imel kam opreti. Očitno

1 Ivan Klemenčič, Zgodovinska avantgarda v slovenski glasbi, Tank! Slovenska zgodovinska avantgarda, ur. Breda Ilich Klančnik in Igor Zabel, Ljubljana 1998-1999, 110-116 (Muzikološki zbornik, 22, Ljubljana 1986, 21-28 in 24, 1988 , 114). - K temu dejstvu so pripomogle še posebne okoliščine, tako Kogojeva duševna bolezen po 1932 in Osterčeva smrt takoj po začetku svetovne vojne. 
pa je bil s svojo glasbo tudi prodoren in pozneje $z$ velikim opusom nenehno navzoč v glasbeni javnosti, dasiravno ga je širši krog poslušalstva sprva zavračal in ga je začel postopno sprejemati; a kakorkoli že lahko notranji stik z njegovo glasbo problematiziramo, je obveljal za pomembno in priznano skladateljsko osebnost. V tem procesu uveljavljanja se je izkazal kot sodobnik, ki je izšel iz neoklasicizma in tradicije Osterčeve šole kot mojstrov zadnji, najuspešnejši učenec in tisti, ki je Osterčevo avantgardno izročilo v novem duhu nadaljeval.

Ko se v letu skladateljeve smrti oziramo na njegovo ustvarjalno pot in delo, nas v enem in drugem še posebno zanima Ramovšev notranji razvoj in s tem oblikovanje umetnika kot umetniškega subjekta. Zanima nas torej njegova skladateljska identiteta - ta mu konec koncev odmerja mesto v slovenski glasbi -, kot jo okvirno zamejuje naslov tega prispevka. Če se pri tem zdi izhodiščno poimenovanje, poistovetenje z zvočnim svetom že večkrat uporabljeno in nekako izrabljeno, se izkaže, da je prav Ramovševemu ustvarjanju, njegovemu temeljnemu razmerju do zvoka kar najbliže, za skladatelja kar najznačilnejše. Potrditev zanj bi navsezadnje našli že v dosedanjem skladateljevem pričevanju o sebi in v misli o njem. ${ }^{2}$

Oblikovanje Primoža Ramovša skladatelja, in to še dolgo v povojni čas, ni bil samoumeven proces, kot se je morda dolgo zdelo in se ga je ne vedno ustrezno razumevalo. Spričo dejstev in okoliščin se vprašanje njegovega predavantgardnega identitetnega izhodišča, prizadevanja priti k sebi, najti sebe, danes znova in kompleksneje zastavlja. Vsekakor to oblikovanje odločilno zaznamuje študij pri Slavku Ostercu, ki se konča po osmih letih stikov in profesorjeve podpore z diplomo na ljubljanski Glasbeni akademiji v letu mojstrove smrti 1941. Osterc je bil na Slovenskem, objektivno gledano, edina prava osebnost kot pobornik sodobne glasbe in zanj takrat edina avtoriteta. Po Kogoju je odločno prelamljal s tradicijo tonalne glasbe in estetike, zato s starejšo generacijo večidel ni imel stika in razumevanja. Ramovš ga je sicer sprejemal kot pobornika novega s klasicizmom, ${ }^{3}$ kar je Osterc nemara bil tudi kot profesor najizraziteje, čeprav je iz njegovega ustvarjanja in iz objavljenih nazorov od leta 1934 razvidno, da se je kot ustvarjalec od Stravinskega vrnil k Schönbergu, k drugi dunajski šoli in k estetiki svojega profesorja Hábe. ${ }^{4}$ Kot neoklasicistični skladatelj ne bi mogel biti avantgardist, le "postmodernist", a v tedanji in še sprva povojni zavesti je s svojim racionalizmom veljal za neoklasicista. ${ }^{5}$ Vsekakor pa sta bila Ostercu in na svoj način Ramovšu blizu tako racionalizem kot kompozicijska naprednost, vendar iz svetovnonazorsko nasprotujočih si izhodišč.

2 Andrej Rijavec, The stylistic orientation of Primož Ramovš, Muzikološki zbornik, 10, Ljubljana 1974 in Borut Loparnik, Biti skladatelj. Pogovori s Primožem Ramovšem, Ljubljana 1984.

3 Po Ramovševem mnenju je pretrgal s tradicijo in uveljavljal "naprednost v neoklasicističnem smislu.u - B. Loparnik, op. cit., 50.

4 Ivan Klemenčič, Slovenski glasbeni ekspresionizem, Ljubljana 1988, 114-118 in 125-135 in isti, Slavko Osterc med neoklasicizmom in ekspresionizmom, Muzikološki zbornik, 31, Ljubljana 1995, 11-23 (Slavko Osterc composing between neoclassicism and expressionism, Slovenski glasbeni dnevi / Slowenische Musiktage 1995, Glasba med obema vojnama in Slavko Osterc / Musik zwischen beiden Weltkriegen und Slavko Osterc, Ljubljana 1995, 49-63).

5 Ramovš se spominja, da so $v$ Osterčevem razredu razpravljali o novih slogovnih gibanjih, in to večidel o neoklasicizmu, ker da je bil v Evropi "vodilni tok", medtem ko je presodil, da Schönbergova smer Osterca ni zanimala in da o njej niso "veliko govorili». - B. Loparnik, op. cit., 49. 
Odtod paradoks, da je Osterc kot ateist komponiral nekaj prepričljivih religioznih koncertnih del in $\mathrm{v}$ posvetno glasbo večkrat vpletal korale, nemara po vzoru Stravinskega, medtem ko je bil Ramovš predan katolik, ki zaradi notranjega odpora skorajda ni pisal cerkvene glasbe, a je v cerkvi še izpred vojne in po njej redno orglal in zlasti prepričljivo improviziral. In v podobni duhovni klimi, le z doslednim študijem strogega stavka, se je Ramovševo kompozicijsko izpopolnjevanje med vojno končalo - njegov zadnji pomembni profesor, Alfredo Casella, je bil namreč kot skladatelj racionalist in napredno usmerjeni klasicist. Še več, z Ostercem sta se poznala in po Ramovševi presoji zelo cenila. ${ }^{6}$ Casella, ki je Ramovšu Osterca velikokrat omenjal, je govoril o njem z velikim spoštovanjem, "da je eden voditeljev evropske glasbe. ${ }^{7}$ Nemara sta prav Osterčeva zgodnja smrt in $z$ njo vojna pripomogla, da ni Ramovš kot njegovi predhodniki iz Osterčevega razreda nadaljeval študija v Pragi, praviloma tudi pri Hábi, marveč v Rimu. Tako mu po vojni v petdesetih letih ni bila prihranjena razmeroma dolga pot iskanja od vrednot objektivne k vrednotam ekspresivne glasbe, in to še v posebnih družbenih razmerah.

Najznačilnejši dosežek tega prvega Ramovševega ustvarjalnega obdobja in že kar njegov sklep je dobro znana in sprejeta Sinfonietta za orkester (1951). Ramovš je torej kompozicijsko nadaljeval v obdobju, ko so se družbene razmere povsem spremenile, $z$ isto Osterčevo in "italijansko" estetiko in nemara še z novimi vplivi kakšnega Šostakoviča. Oprl se je torej na znano, preskušeno in še dopustno, ker je bila Jugoslavija še v petdesetih letih ideološko zaprta država in je bil prvi val političnega liberalizma in reformizma zaznaven šele v šestdesetih letih. Tako je še 1957. potekala ideološka partijska polemika o svobodi umetniškega ustvarjanja med trdim dogmatizmom vodilnega ideologa Borisa Ziherla in Josipom Vidmarjem, ki se je zavzemal za popolno svobodo ustvarjanja, a je bil ne dolgo zatem tudi zavzet nasprotnik vsakršnega modernizma. ${ }^{8}$ Tako se je le počasi in postopno širil prostor svobode umetniškega ustvarjanja, ki ga v letu 1951 še posebno zaznamuje ideološka obsodba novel Edvarda Kocbeka Strah in pogum, s katero so pisatelja in politika eksemplarično izločili za desetletje iz javnosti. Nedvomno je moral "strah in pogum" na svoj način spremljati tudi Primoža Ramovša, ki so ga v letu t. i. osvoboditve 1945 kot domobranca obdolžili sovražne propagande in za tri mesece zaprli.

V istem letu 1951 sta nastali še slogovno podobni in muzikalno vsaka po svoje prepričljivi Druga suita za godala Marijana Lipovška in Simfonietta Uroša Kreka. Tako se je neoklasicizem, tudi po zgledih iz Sovjetske zveze, na Slovenskem uveljavil kot možni in takrat najnaprednejši dosežek znotraj ideološko predpisane umetnosti, četudi je pri nekaterih skladateljih s konca štiridesetih in več v petdesetih

Prim. obsežno polemiko v Naši sodobnosti 1957 in še 1958. - Ivan Klemenčič, Glasba in totalitarna država na Slovenskem, Temna stran meseca. Kratka zgodovina totalitarizma v Sloveniji, 1945-1990. Zbornik člankov in dokumentov, ur. D. Jančar, Ljubljana 1998, 329 (Nova revija, 17, št. 194-195, Ljubljana 1998, 226; Music and the Totalitarian State in Slovenia, Glasba in družba $v$ 20. stoletju / Music and Society in the $20^{\text {h }}$ Century. Slovenski glasbeni dnevi 1998, ur. P. Kuret, Ljubljana 1999, 60).
} 
že lahko segel onkraj v disharmonijo ekspresionizma, torej ideološko zavračane formalistične ali dekadentne umetnosti. ${ }^{9}$ Ramovš mu je dal pečat svoje asketske muzikalnosti in muzikalne elokvence, tudi $z$ nekaj ljudskega duha. To je bila optimistična in sproščena objektivistična, v glasbenem času ontološko pogojena glasba, ki temelji na motoriki in jo še posebej zaznamujejo igrivost, polétnost, odločnost. Bolj kot parodiranje klasicizma in tudi baroka je ustvarjena v novem duhu, kakor ga poznata Hindemith in precej tudi Osterc.

Kljub temu "strahu in pogumu" se Ramovš prepričano spominja, da je takrat komponiral, kot je sam mislil, da je prav, da v ustvarjalnem smislu ni občutil pritiskov ali omejitev. ${ }^{10}$ Če imamo v mislih konec petdesetih let, šestdeseta leta in naprej, to nedvomno drži, deloma še za petdeseta leta, ko gre že tudi za subjektivni občutek svobode in tembolj za povojni čas pred njimi. Vemo namreč, da se je napredna zahodnoevropska glasba $v$ tem času razvijala precej drugače, na prehodu v petdeseta leta je že postavila prve temelje novemu avantgardizmu. ${ }^{11}$ Posredni primer na Slovenskem nam od leta 1950 daje politični emigrant Božidar Kantušer, ${ }^{12}$ ki se je seznanil z rezultati poletnih tečajev v Darmstadtu, ne da bi tamkajšnji serializem scela sprejel, kot ni nikakor hotel biti avantgardist, a je bil kot učenec Oliviera Messiaena $v$ letih 1952-1953 vendar napredno usmerjen. Njegov prvi godalni kvartet (1953), nastal v duhu poudarjenega izpovednega subjektivizma, je v gotovosti svoje ekspresionistične drže in v svoji duhovnodisharmonični izraznosti takrat nehote najbolj radikalna slovenska skladba. Tako se vendarle odpira vprašanje socialističnega realizma, če že ne modela, ki ni bil v glasbi jasno predstavljen, vsekakor ideološke klime od zapovedanosti optimizma do zanikanja izpovednosti in subjektivizma. Zato je poleg Ramovša nemara lahko razmišljal še kateri slovenskih skladateljev, da se ni čutil ustvarjalno utesnjenega, ko je še predvsem podzavestno sprejemal utesnjenega duha svojega časa. Če primerjamo slovensko glasbo prvega poldrugega desetletja $\mathrm{z}$ zahodnoevropsko, vsekakor vidimo, da jo podobno kot drugo iz komunističnega bloka obvladuje povsem drug duh. Ob ustvarjalni svobodi in odprtosti $\mathrm{z}$ neovirano menjavo informacij bi razvoj nedvomno potekal drugače, vsekakor hitreje, kar smemo domnevati tudi za Ramovša in njegovo skladateljsko oblikovanje, ne le zato, ker študija ni nadaljeval pri Hábi. Nazoren primer nam daje njegova Tretja simfonija (1948), nastala pod vplivi Šostakoviča, kakor jo razlaga Andrej Rijavec: "Sklepni stavek vsebuje značilno slogovno potezo, ki je z vidika sedanje Ramovševe usmerjenosti [tj. do začetka sedemdesetih let] tembolj presenetljiva: zmagoviti dorski sklep s poudarjenimi pihali, trobili in timpani je pozornost vzbujajoč primer himničnega socialističnega realizma. ${ }^{13}$ Tako se izkaže, da je bil

9 I. Klemenčič, Glasba in totalitarna država na Slovenskem, Temna stran meseca, 328-329 (Nova revija, 223).

10 Ramovševa izjava avtorju tega besedila v razgovoru spomladi 1997.

11 Prim. zlasti Messiaenov pomen za razvoj serializma s klavirsko skladbo Mode de valeurs et d'intensités iz 1949 in Boulezov prispevek k punktualizmu s Structure Ia za dva klavirja iz 1952. Isto leto je začenjal Cage z aleatoriko, ki so se ji pridružili evropski skladatelji s Stockhausnom in Boulezom štiri, pet let pozneje. Konkretno in elektronsko glasbo so začeli razvijati na prehodu v petdeseta leta. Lahko rečemo, da je evropska avantgarda začenjala svojo pot $v$ letih takoj po končani drugi svetovni vojni.

12 Skladateljeva izjava avtorju tega besedila, demokrata, ki je v več pogovorih še v osemdesetih letih potrjeval, da ni sprejemal povojnega režima na Slovenskem.

13 A. Rijavec, op. cit., 82 . 
skladateljev občutek svobode in notranje zadoščenosti eno, vpliv totalitarne družbe z ideloško in drugo represijo pa drugo in sicer odločujoče za skladateljevo trenutno in širšo usmerjenost in za tedanjo slovensko glasbo nasploh. ${ }^{14}$

Ko obravnavamo ta ustvarjalni vidik in $z$ njim ujetost $v$ čas, je treba opozoriti še na nasprotni vidik iz istih let, ki kaže, da je bil Ramovš zmožen stopiti iz svojega časa. Če se namreč še Sinfonietta vključuje v takratno relativno napredno slovensko glasbo, tega ne moremo trditi za eno samo delo tega obdobja, za klavirske Sarkazme, nastale še v istem letu pred to simfonično skladbo. V njih je skladatelj zmogel stopiti korak nazaj, zmogel je kritiko in kritično razdaljo, bodisi $z$ ironijo in $z$ jedkim posmehom ali z norčevanjem, kot nihče tedaj na Slovenskem. Gre za najbolj prelomno Ramovševo skladbo pred sprejetjem avantgardizma, čeprav je resda pozneje v petdesetih letih še stopnjeval ostrino zvoka in sprejel atonalno abstrakcijo izraza, medtem ko njena sicer še tonalna zasnova seže največ do bitonalnosti in tolkalne vloge glasbila. Zlasti v tretjem izmed devetih sarkazmomv, ki jih je napisal, ne da bi prej poznal istoimenske skladbe Prokofjeva, je uveljavil že takrat značilne dinamične in vsebinske kontraste: akorde $z$ zbrano poglobljenostjo in mirom ter $z$ njihovim norčavim odzvenom in nadaljeval $z$ ironično izpeljavo vse do duhovitega, posmehljivo navrženega sklepa, kar je pomenilo razvrednotenje vrednot ali navideznost takšnih vrednot. Rečemo lahko, za tisti čas nekako "neodgovorna", samosvoja, kljub vsemu in za svoj prav narejena glasba. Glasba notranjega upora kot napoved samosvoje poti $\mathrm{v}$ avantgardizem.

Vmes je poteklo domala desetletje preobrazbe, preusmerjanja v subjektivizem ekspresionizma, ki ga je skladatelj resda pojmoval kot nadaljevanje neoklasicizma, ${ }^{15}$ a je pomenilo popoln razhod $\mathrm{z}$ ideološko zapovedano umetnostjo in obenem postopno dohitevanje napredne zahodnoevropske. Delo tega drugega obdobja, v katerem že pride podzavestno do prevladujočega sprejetja novih vrednot, so markantne orkestralne Musiques funèbres (1955), nastale kot žalna glasba ob materini smrti. Označuje jih nova in močno poudarjena disharmonija in z njo prizadevanje k nepredmetnemu, abstraktnemu izrazu. Vertikalno se kvartni in drugi akordi kot ostre disonance družijo horizontalno z melodično zaostrenimi poltonskimi postopi. V tem smislu je novi, racionalno utemeljeni in asketski, a seveda intuitivno nastali izrazni način oblikovan. Harmonska funkcionalnost se začenja

14 Nelogično bi bilo pričakovati, da bi bil v represivni državi pri totalnem nadzoru družbe izvzet katerikoli njen del ali podsistem, zato tudi vsak posebej in vsi skupaj izpričujejo zastoj oziroma zaostajanje $\mathrm{v}$ primerjavi $\mathrm{z}$ zahodnoevropsko civilizacijo. $\mathrm{V}$ umetniškem in posebej glasbenem ustvarjanju obsega kritično obdobje na Slovenskem približno poldrugo desetletje po končani vojni (prim. tudi Ivan Klemenčič, Glasba in totalitarna država na Slovenskem, gl. tu opombo 8), medtem ko se je v političnem in gospodarskem življenju ter kadrovsko ideološki nadzor ohranil vse do prvih demokratičnih volitev aprila 1990. Odtod je zastoj za Zahodno Evropo tudi kvantitativno merljiv, denimo pri nacionalnem dohodku na prebivalca, kjer je Slovenija zaostala s primerljivima sosedama Avstrijo in Italijo za približno trikrat do štirikrat. Tako se eksaktno potrjuje teza filozofa Francisa Fukuyame o demokraciji kot pogoju za gospodarski napredek in številčna merljivost še posredno potrjuje duhovno zaostajanje kot posledico uničevanja civilizacijskih vrednot družbe. Končni dokaz za to je bil propad komunizma.

15 B. Loparnik, op. cit., 125 (še po sredi petdeseth let se hoče "otresti tako imenovanega klasicizma in klasicistične gradnje“; Koncert za violino in violo iz 1961 je "še zmeraj zasidran v klasicizmu, je pa že jasen odklon od tonalnosti...; podobno 126), 130 (še vernost klasicističnemu načinu oblikovne gradnje), 135 (šele z dodekafonskimi skladbami se otrese klasicizma, "vsaj tistega strogega"). 
izgubljati, medsebojna povezanost šestih stavkov izgubi klasicistično preglednost, lahko pa kakšen akord sem in tja še ohrani hindemithovski prizven nove stvarnosti. Obenem se $z$ disharmonijo, ki vodi do ekspresije, tu prvič uveljavi tako značilna ramovševska dramatika. Doslednejša izpeljava te estetike petdesetih let, ki se začenja oblikovati že pod vplivom Varšavske jeseni 1. 1960, je Koncert za violino violo in orkester (1961), delo hkrati s pogledom nazaj in naprej. ${ }^{16}$ Arabeskno muzikalno tkanje obeh solističnih glasbil in posebej tudi orkestra v četrtem stavku Allegro molto, ki izgubi funkcionalno zvezo s tonalnostjo, ima nedvomno vzporednice pri Ostercu, še posebno v njegovih klavirskih Arabeskah kot primeru poznoekspresionistične igre $z$ izpraznjeno tragično vsebino, ki zadobiva pri Ramovšu novo dramatično težo. Novi in prvič uporabljeni so pod vplivom Varšavske jeseni tonski grozdi, le notirani še niso v novem aleatoričnem smislu. ${ }^{17}$

Kot ugotavlja skladatelj sam, se je začel vedno bolj umikati v politonalnost, atonalnost in je vertikalno izostril svoj $\mathrm{zvok}^{18}{ }^{18}$ nato pa je v kratkem dveletnem obdobju prešel dodekafonijo oziroma serialnost ter dosegel skrajno točko tega razvoja v totalni organizaciji Pentektasisa (1963). To je v letu 1961 čas nastanka Kontrastov za klavirski trio in naslednje leto Dialogov za dva klavirja, Intrade za orkester in Zvočne slike za rog in klavir. Za Ramovša so bila ta dela pomembna zato, ker se je $\mathrm{z}$ njimi poslovil od stare estetike, ki jo je, kot vemo, še vedno poimenoval in razumeval kot klasicistično. Po desetletju transformacije je bila to nemara že posledica pospeška, ki ga je na prehodu v šestdeseta leta dobil ob odpiranju takratne jugoslovanske države Zahodni Evropi, neposredno pa posledica predvsem odločilnega obiska festivala Varšavske jeseni 1. 1960 in še leto pozneje prvega zagrebškega glasbenega bienala. Vendar je skladatelj želel zavestno in sistematično preiti serialno fazo, tako je tudi s Pentektasisom dosegel avantgardo, ki mu je pokazala, da se je znašel v slepi ulici, v smeri, ki ne ustreza njegovemu umetniškemu bistvu, se pravi neposrednosti njegovega odzivanja. Leto 1963 je bilo torej prelomno, čas odvrnitve od izročila Darmstadta. S kompozicijskotehnično izdelavo Pentektasisa je bil resda zadovoljen, ker je $\mathrm{z}$ njim dosegel obvladovanje popolne serialne organizacije kompoziciskega stavka, vendar je bil rezultat zanj robotska, enolično siva glasba, v kateri ni našel svoje identitete: "Ne čutim, da je to moje delo." ${ }^{19} \mathrm{Kaj}$ je torej bistvenega pričakoval od nove glasbe? Tako smo prišli do osrednjega skladateljevega stališča, za katerega je bil priznaval, da je konservativno, zato pač, ker je v glasbi še vedno pričakoval "neko doživetje, popolnoma tonsko, imaginarno doživetje," po katerem je čutil, da postaja bogatejši. Drugače rečeno, prepričan je bil, "da mora vsaka skladba nekaj povedati. ${ }^{20}$

Rešitev tega, kar je iskal in slutil, je v največji meri našel predvsem v novi poljski glasbi, ki je bila zaradi takšne svoje narave najbliže še kateremu slovenskih skladateljev, ki ga ni prevzela metodološka strogost serializma, s katero naj bi dušil

\footnotetext{
16 Prim. za to skladbo še predhodno opombo.

17 B. Loparnik, op. cit., 126.

18 Ib., 125.

19 Ib., 138.

20 Ib., 138-139.
} 
invencijo, blizu denimo Lojzetu Lebiču ali Ivu Petriću. Ramovš je kompozicijske novosti v skladu s svojim načinom odzivanja sprejel navdušeno: "Varšava mi je pokazala sintezo, napredek na vseh območjih hkrati, vzporedno v zvoku, obliki, harmoniji, instrumentaciji, barvah. Vse novo", brez "naslona na preteklost “. ${ }^{21}$ Vendar reakcija skladatelja na novo očitno ni mogla biti hipna, temmanj trenutna modna, marveč globlja vsebinska, odločilna za njegovo identifikacijo. Ker je sam menil, da ob zavestnem premišljevanju pravi proces prevrednotenja poteka podzavestno, ${ }^{22} \mathrm{se}$ je izkazalo, da je bil zanj rabil značilna tri leta. Vstop v novo svobodo ustvarjanja mu je tako prinesla zlasti forma, ki ni bila več kakorkoli vnaprej dana. Kljub racionalnim izhodiščem in nadzoru zato skladătelj poslej sprejema iracionalni, nepredvidljivi način improvizacije, takojšnjega reagiranja in $s$ tem muzikalne gradnje. Če je vstop v ta novi svet aleatorike pomenila Enneaphonia za komorni ansambel (1963), ki je bila v letu nastanka prvič izvedena na Varšavski jeseni z Ansamblom Slavko Osterc pod vodstvom Iva Petrića in je tako $z$ njo skladatelj vračal, kar je tam pridobil, pomeni Simfonija 68(1968) že izoblikovanje ustvarjalčevega novega glasbenega jezika, s katerim se je izčistil v subjektivizem modernizma. Po njej je le še v novem duhu izpopolnil notni zapis, zvočna podoba je ostala večidel takšna, kot jo zatem značilno prepoznavamo in spremljamo v vsem velikem skladateljevem opusu prek štiristo del. Kompozicijskotehnično jo je utemeljil na svobodni atonalnosti z dokaj izpisano aleatoriko, na svobodni, a nadzorovani improvizacijski obliki in na ostrini disonance $\mathrm{v}$ harmonskem in tudi $\mathrm{v}$ melodičnem smislu, se pravi s "povednimi " jedri poltonskih melodičnih postopov, kar pomeni svobodno uporabo dvanajsttonske tehnike.

Kakšne so poslej lahko pobude za nastanek del, so predvsem čistoglasbene ali so zunajglasbene? Skladatelj vsekakor dopušča možnost, da dobiva ob zgolj muzikalnih tudi zamisli iz zunanjega sveta, vendar jih preoblikuje v čisto, absolutno glasbo. Izhodišče tako dobljene muzikalne abstrakcije je torej čisti zvok, to je nedvomno srž Ramovševe glasbene estetike, zato tudi v njegovem opusu takorekoč izključno inštrumental. In vendar: skladatelj se zaveda, da s tako ustvarjenim svetom čiste glasbe posredno izraža tudi svoj duševni in duhovni svet. ${ }^{23}$ Se pravi, zvočni svet je izraz osebnostnega sveta in kot tak izraz poudarjenega subjektivizma. Izkaže se, da to ni intimni svet, četudi pozna in lahko izraža liričnost. Njegova asketska muzikalnost se utemeljuje na subjektivizmu pripovedi, četudi v popolni nepredmetni abstrakciji, pogosto temelji celo na poudarjeni "zgovornosti", kakršno dobro poznamo iz skladateljeve človeške komunikacije, na elokventnosti torej. Odtod, iz te temeljne izrazne drže, iz te pripovedne ekstravertiranosti prihaja do vsakršnih močnih osebnostnih reakcij, do zvočnih presenečenj in kontrastov, pogosto do značilnih izbruhov dramatike in kataklizmike. Prav v tem elementu je Ramovš, čeprav ne osamljen, najbolj izrazit dramatik v slovenski glasbi.

21 Ib., 128.

22 Ib., 134 .

23 Gl. opombo 10. 


\section{MUZIKOLOŠKI ZBORNIK • MUSICOLOGICAL ANNUAL XXXV}

$\mathrm{Na}$ tako dobljenem čistem zvoku $\mathrm{z}$ njegovim duševnim in duhovnim ozadjem temelji tudi Simfonija 68. Začenši s poimenovanjem, ki več ne pomeni nekdanje klasične oblike, marveč v prvobitnem grškem pomenu pojav sozvenenja, pri čemer se njen novi kleni zvok vsebinsko osmišlja na življenjski konkretnosti, v nemirnem letu 1968 svetovne zgodovine. Neposredne spodbude za skladateljev protest so bili, kot se spominja, begunci iz afriške Biafre in začetek vojne v Vietnamu ${ }^{24}$ ter še češka kriza. Vendar se skladatelj širše spominja občutja tesnobe in nemira okrog sebe, spominja se, kako ga je prešinjal strah pred tretjo svetovno vojno, ki bi lahko uničila ves svet ${ }^{25}$ in to občutje je želel izraziti s tonsko govorico. Resda ne prvič, ker bi prve slutnje našli že v Koncertu za violino, violo in orkester ali v drugem stavku Odmevov za flavto in orkester (1965), ${ }^{26}$ vendarle zavestno izoblikovano in osredotočeno šele v Simfoniji 68. Z njo postane očitno, da nastopajoči atomski vek in duh modernizma lahko poslej izrazi in simbolizira le govorica skrajnega subjektivizma, ${ }^{27}$ se pravi novo doživetje sveta v skladu z novimi izraznimi možnostmi. Dvostavčno delo zgolj z metronomskimi označbami temelji tako na že znanih kontrastih: prvi stavek je počasen in $\mathrm{v}$ svoji tridelnosti $\mathrm{z}$ agresivnimi dinamičnimi razponi vertikalen, drugi hitri je njegovo linearno dopolnilo $\mathrm{z}$ razgibanostjo in eruptivnimi, kataklizmičnimi viški. Čista glasba torej, asketska glasba, vendar zgovorna v zvočni pojavnosti med statiko in dinamiko, pomenljivo tišino in dramatiko.

Tako ni dvoma, da stoji skladatelj intenzivno in prizadeto sredi življenja in da doživlja njegove napetosti in stiske, a lahko tudi njegovo lepoto povsem po svoje, $s$ čimer se oblikuje kot umetniški subjekt: „Komponist si v nekem trenutku izoblikuje svoje nazore, svoje estetske poglede čisto brez ozira na okolico, in ti nazori so za tisti trenutek bistveni.."28 Psihološka umetniška osnova tega skrajnega, do vsakega trenutka prignanega subjektivizma so v pripoved prenesena iracionalna duševna stanja, njegove zgostitve in sprostitve, so na nasprotjih temelječa sporočilnost kot skladatelju prirojeni način izražanja in odzivanja, osredotočenost na skrajnosti in razpone dinamike, pa tonske višine in trajanja tonov, tempa, tudi občutja disonance, so izhodiščno gibalo, gonilna sila, ki vzdržuje napetost, zlasti še daljših del. Našli bi jih celo v skladbah, kjer bi jih že težje pričakovali, denimo v Pianissimu (1974) znotraj subtilnih razpoloženj, po skladateljevi razlagi namesto dinamičnih kot utemeljenost vsebinskih nasprotij med solistom in komornim ansamblom, med dolgimi in kratkimi toni ipd. ${ }^{29}$ Izrazno izhodišče tega včasih prav eksaltiranega pripovednega subjektivizma, njegovo temeljno razmerje do sveta in s tem njegovo dojemanje, je doslej najbolj duhovno in v tej poduhovljenosti abstraktno "nepredmetno". Predmetnost takšnega subjektivizma je že zdavnaj presežena, že po Schönbergu je postala nezanimiva, saj umetnik ekspresionist ko denimo portretira, v višjem smislu

24 Gl. opombo 10.

25 Prim. B. Loparnik, op. cit., 158-159.

26 Ib., 160.

27 Ali s skladateljevimi besedami: "Svojo eksistenco v nekem času in nekem prostoru je treba prenesti v glasbeni svet in jo tam izraziti.، Ib., 162.

28 Ib.

29 Ib., 214. 
portretira le sebe; ${ }^{30}$ tako tudi skladatelj izraža samo sebe, glasba je njegov psihogram, kjer bi predmetnost, opisnost tonalnosti le prikrivala bistvo. Z njim se druži druga temeljna sestavina tega subjektivizma, disharmonično občutje sveta kot neposredni in lahko prav brezobzirni izraz notranje resničnosti, s tem pa skrajno nasprotje estetiki idealizirane lepotnosti in harmoničnosti 19. stoletja. Novo razmerje do sveta torej kot nov subjektivno stopnjevani izrazni način in že kar nova modernistična norma, ob skladateljih Vinku Globokarju, Lojzetu Lebiču in še kom najbolj zaostren, lahko rečemo najbolj v vsej slovenski glasbi doslej.

Tako se je po drugi vojni izoblikoval skladateljev umetniški subjekt, umetniški organ, ki je segel v izrazitem loku od upodabljanja objektivnega sveta ali zgolj njegovega abstraktnega občutja znotraj razširjene tonalnosti na začetku petdesetih let, se pravi od sprejemanja tega sveta kot objektivnega dejstva, do svojega nasprotja, do novega subjektivnega razmerja do sveta onstran tonalnosti in še s serialnimi tehnikami ter privedel do poudarjenega subjektivizma aleatorične estetike. Razvoj v treh stopnjah $z$ dvema temeljnima identitetama torej, skozi katerega se je v kompozicijskotehničnem smislu novo duhovno in disharmonično občutje sveta izkristaliziralo kot model vsakršne nove organiziranosti s svobodno formo in svobodno dodekafonijo ter $\mathrm{z}$ vertikalno poudarjeno disonančnostjo $\mathrm{z}$ najbolj zaostrenimi intervali malih sekund, zvečanih kvart in velikih septim. Tako dobljena, na nenehnem kontrastu temelječa disharmonija $\mathrm{z}$ dramatiko, kataklizmiko, krikom poslej govori o kriznem stanju jaza. Gre za modernizirano, z novimi kompozicijskimi sredstvi podkrepljeno vzporednico srednjemu ekspresionizmu, ko se njegovo bistvo najmočneje izrazi. ${ }^{31}$ Pri Ramovšu ta srednja faza modernizma deloma prehaja v pozno, tj. $v$ načelno sprejeto preusmeritev in lahko $v$ izmiritev, bodisi $z$ racionaliziranjem ali neposredno $z$ vključitvijo prej poudarjene disonance $v$ glasbeni tok, kot to denimo zasledimo pri Lebiču ali Globokarju, pri zadnjem sicer še vedno z najbolj načelno, tj. notranje nepomirljivo in s tem radikalno držo.

Poslej, po tem osebnostnem formiranju, se Ramovš v svojem ustvarjalnem naponu predvsem variira in obnavlja, zaradi močne zvestobe svojemu modernizmu lahko tudi ponavlja. Posebno pogosto se vživlja v vsemogoče zasedbe zlasti v koncertantnih delih, ki jih piše po naročilu prijateljev in znancev solistov, ansamblov. Še $\mathrm{v}$ letih visoke starosti se nanje odziva zavzeto, radoživo in spet $\mathrm{z}$ navdušenjem do konca dejaven, dokler mu bolezen ne ustavi skladateljskega peresa. In že v naslednjem desetletju po uveljavitvi avantgarde, leta 1971, potem ko je obvladal zvočno gradivo, se mu postavi pravzaprav izhodiščno vprašanje, zakaj komponirati. To ga ne vodi morda v eksperimentalno raziskovanje zvoka, marveč "V raziskovanje izraza, vsebine.$^{32}$ Podobno kot se odziva Vinko Globokar, ki občuti tri leta pozneje sivino kompozicijskih sredstev, nesmisel iskanja še novih zvočnih gradiv, in najde resnično novost v služenju ideji in s tem vključevanju problematike zunajmuzikalnega sveta.

30 Arnold Schönberg, The relationship to the text (1912). Arnold Schönberg, Style and idea, London 1975, 145. - Prim tudi Ivan Klemenčič, Ekspresionizem kot glasbeni slog, Muzikološki zbornik, 17, Ljubljana 1981, št. 2, 36.

31 Ivan Klemenčič, op. cit., 35.

32 B. Loparnik, op. cit., 170. 
Ko se po šestdesetih letih Ramovšev izraz po eni strani še stopnjuje v poudarjeno disharmonijo, se začne v izčiščenem izrazu, kjer ni več poudarka na oblikovanju zvočnega gradiva, uveljavljati tudi "klasična lepota", uravnoteženost skladne, odtehtane notranje napetosti. Po drugi strani mu opustitev taktnic omogoči "prelivanje, sproščenost", pojavljajo se zvočne ploskve kot nosilci izraza, prejšnjo melodično linearnost kot pomemben gradbeni element zamenja tako linearnost zvočnih ploskev. ${ }^{33}$ Če je torej skladatelj menil, da je s Sintezami za rog in tri orkestrske skupine (1971) dosegel mejnik v obvladanju novega zvoka, se mu je s Simfoničnim portretom (1972) postavilo načelno vprašanje, kam naprej, ${ }^{34}$ na katerega si verjetno ni mogel dokončno odgovoriti, $z$ njim je najbrž moral živeti.

Prav z vprašanjem osmislitve skladanja prihajamo tudi širše do Ramovševe misli o glasbenem ustvarjanju, ki je že doslej opozarjala nase in kakršno si je izoblikoval predvsem stvarno, ker ni bil dovzeten za načelno in abstraktno teoretiziranje in estetiziranje. S premislekom o svoji umetnosti je zlasti dokazoval zvestobo abstraktni naravi zvoka in s tem zvestobo muzikalni povednosti, njeni "vsebini", ki se tudi pri zunajglasbenih pobudah sublimira v čisti zvok. Za Ramovša skladatelja in ne morda filozofa ali politika je pomembno, da zunanji svet nanj vpliva predvsem podzavestno, čeprav to ne pomeni zgolj njegovega pasivnega sprejemanja. Zunanji svet je del življenja, ki teče skozenj, vendar $z$ jasnim poslanstvom odgovornosti in "avantgardne predhodnice". "Toda umetnik sodi med tiste, ki življenje ... tudi izoblikujejo in usmerjajo." Bil naj bi "pred časom, da napoveduje, kaj bo prišlo." Ali kot še drugače pravi: "Stojiš v danes, tvoje korenine so v včerajšnjem, gledaš pa v jutri.. ${ }^{35}$ Zunanji svet torej vpliva na estetskega, vendar mora biti umetnikova vloga, če naj je ustvarjalna, dejavna, pred časom tako z govorico kot $z$ idejami.

Odtod se izrisuje skladateljeva identiteta, ki je v specifiki glasbenega izraza in seveda v njegovem čistoglasbenem liku, katerega vsebina se po Ramovšu nikakor ne da izraziti $z$ besedami. ${ }^{36}$ Glasba zahteva torej svojo logiko, bodisi čistoglasbeno ali kot izraz kakega posebnega občutja sveta. Zato pravi: "Čista, prava glasba ... je samo abstraktna. ${ }^{37} \mathrm{~V}$ modernizmu torej dvakratna abstrakcija še $\mathrm{z}$ "nepredmetno" atonalno glasbo, katere emanacija je spet čisti zvok, zvok tonov in šumov. V njem je $s$ skladateljevo individualno izrazno identiteto vsebovana tudi nacionalna identiteta, čeprav tudi o njej kot o vsebini glasbe skladatelj ne more povedati nič oprijemljivega: "Slovenec sem, torej je moje ustvarjanje slovensko." ${ }^{38}$ Se pravi, če se je kot pripadnik naroda prepričljivo izrazil, je prav tako izrazil svoje nacionalno bistvo, svojo nacionalno naravo. Vsekakor se povsem zaveda pomembnosti umetnikovega poslanstva še posebno za narod, za oblikovanje njegove identitete: „Ustvarjalec je tisti, ki soustvarja nacionalnost in njeno kulturo." ${ }^{39}$ Odtod je "vsaka kompozicija ...

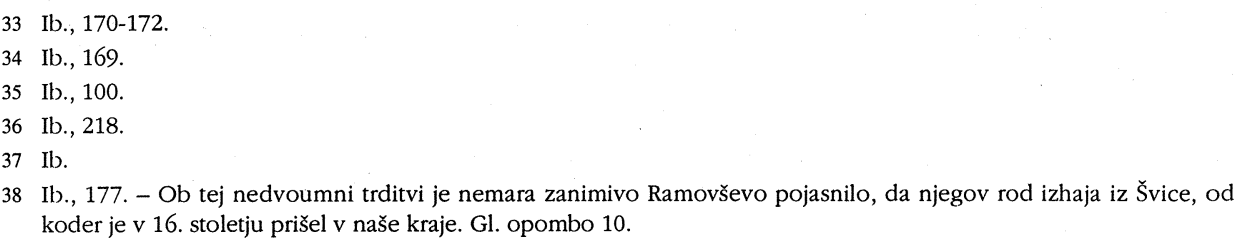


kamenček v mozaiku celotne narodove kulture. “40 Tako celovito sprejema skladanje kot poklic: "Za to delo se čutim poklicanega, to je moja dolžnost do sebe, do drugih, do vsega naroda. “41 Neposredno razmerje te zanj prijetne dolžnosti, ki jo opravlja $v$ pogosto hitro minevajočih nočnih urah, se vzpostavi na individualni ravni, s poslušalcem. Kot že vemo, mu mora skladatelj nekaj dati, povedati, vendar brez koncesij. ${ }^{42}$ Psihološki medij tega ključnega stika je za Ramovša doživetje, ${ }^{43}$ ne torej mišljenje, ne filozofski disput ali teoretiziranje, ne komplicirano umevanje strukture, kar se želi včasih novi glasbi imputirati. Lahko je to iracionalno sprejemanje temeljne ideje, posebnega občutja, ki more voditi do spoznanja in recimo kdaj celo do katarze, ali zgolj neposredno muzikalno doživetje na ravni zvoka, bodisi avtonomno ali asociativno kot kakšna izhodiščna zamisel, brez napisanega programa, neutesnjujoča, prepuščena le poslušalčevi domišljiji in njegovemu odzivanju.

To načelno in zavestno razmerje do ustvarjanja kot konstante se je pri tako plodovitem skladatelju, kot je Primož Ramovš, moralo znova in znova stvarno reševati v smislu zastavljenega vprašanja, kam naprej. Kot ena spontanih možnosti se je v sedemdesetih letih pokazala in utemeljevala $\mathrm{v}$ afiniteti gledanja nazaj, $\mathrm{v}$ reminiscencah na tradicijo. Ne morda v priročnih citatih stare glasbe ali kolažih, ki jih skladatelj vendarle ne pozna, marveč v rabi bolj oprijemljivih tonalnih elementov, kot jih zasledimo v Koncertu za violončelo in orkester (1974) ali v godalnem triu z značilnim naslovom Reminiscences (1977) ter denimo v skladbi Triplum (1980), ki s tem naslovom pojasnjuje tristavčno delo za tri skupine in "trikratnost v mikrostrukturi" ${ }^{44}$ Za osemdeseta leta bi spet lahko rekli, da jih označuje nekoliko več zmernosti, nekoliko bolj konkretna govorica. Tudi kot mislec in govorec je navsezadnje Ramovš vedno zelo konkreten in koncizen. Zelo podobno konkretno, zelo določno in eksaktno se izraža v glasbi, čeprav "dvojno" abstraktno in čeprav to drugo abstrakcijo sem in tja tonalno nekoliko razrahlja. Nekaj več umirjenosti, manj abstraktne odmaknjenosti in neposredne povednosti, tudi z daljšimi utemeljitvami ene glasbene ideje, najdemo v Koncertu za trobento in orkester (1985). Še več umirjenosti in harmoničnosti je v Concertu doppiu za kljunasto in prečno flavto ter orkester (1985), v katerem skladatelj ustvarja občutja, ki jih podaljšuje in postmodernistično umirja. Poleg tega izrazno pomemben je $z$ doseženo zrelostjo in izrazno širino modernizma premik od zvočne askeze k zvočni širini in polnosti. Tako suvereno prepričljiva govorica Organofonije za orgle in orkester (1982) temelji v svoji strnjenosti in konciznem izrisu na izvirnosti in polnosti zvočnih barv, celotnih zvočnih ploskev, zlasti še vsakršnih prepričljivih novih orgelskih, se pravi na zvočnem bogastvu glasbila, $h$ kateremu se je skladatelj večkrat vračal.

Kakor se je s tem v svoji govorici prečistil, je sprejemal tudi hitre rešitve, kar za tako velik opus ni presenetljivo. V celem ga namreč označuje hiter način komponi-

43 Ib.

44 Ib., 219.
} 
ranja (tako rekoč brez popravljanja nazaj), podobno kot pri Ostercu, vendar praviloma na podlagi inspiracije in velike angažiranosti, kar za njegovega mentorja prav vedno ne velja in je izzvalo tudi kritiko njegovih sodobnikov. Odtod pri Ramovšu in njegovi temeljni usmerjenosti v zvok lahko sem in tja pasaža, zvočna skupina, kompozicijska prigodnost, ki ni povsem funkcionalna, ki lahko ostaja na ravni zvočnega dogodka, bolj kot dodatek, zvočno polnilo, hiter odziv. Te zunanjosti se sem in tja oklepajo tudi naslovi skladb, ki skušajo opozarjati na skladateljeva čistoglasbena izhodišča in ki so bili zanj včasih očitno bolj nujno zlo, ko mu je šlo vendar za druge poudarke, za čisti zvok in za čisto muzikalno izpeljavo. Prav mu lahko pridejo tudi zunanjosti, kot je naziv ansambla (Viribus unitis, 1986), ali so drugače neposredno stvarni (Pojoče strune, 1994) ali spet fantazijsko naznačeni (po Prešernu Soneti nesreče, 1992), seveda pa tudi s povsem določno vsebino in dogodki. Takšno vsebino denimo zakriva že v devetdesetih letih nastalo zrelo orkestrsko delo Per aspera ad astra (1991), s katerim se je skladatelj odzval na dogodke ob slovenski osamosvojitvi, ob narodovem daljnosežnem zgodovinskem dejanju osvoboditve iz ječe jugoslovanske narodov. S svojim dragocenim pričevanjem je obudil takratnega duha napetosti in dramatičnosti ob agresiji tuje vojske, občutja pričakovanja in radosti ob osvobojeni domovini, njenem vračanju v naravno evropsko okolje. Od kontrastnih napetosti ob grozečem prihodu ponovnih okupatorjev ter "in medias res vojaških operacij" $Z$ nekaj drastike (govorica orožja, sirena rešilca) je glasbeno avtonomno segel do nenadne umiritve, do pretanjene intime, do prebliskov in občutij asociativnega slavnostnega in navdušujočega vse do silovitega sklepnega crescenda s fanfarami slavja. Tako je s kar virtuoznim obvladovanjem zvočne snovi skladno $\mathrm{z}$ naslovom dela sklenil razgibani doživljajski lok njegove sugestivne, iz materialnosti v duhovnost sublimirane energije.

Skladateljeva zvestoba modernistični usmerjenosti kljub reminiscencam in zvezanostjo $s$ tradicijo ni presahnila niti v devetdesetih letih, vprašanje postmodernizma se torej ni odpiralo, četudi ga je vsebina skladb lahko približala njegovim načelom večje konkretnosti in notranje skladnosti. $Z$ več svobode $v$ rabi kompozicijskih sredstev se je tudi po svojem mnenju postmodernizmu najbolj približal v Simfoniji Pietà (1995), ${ }^{45} \mathrm{ki}$ sodi med Ramovševa najtehtnejša dela in ki je posvečena tragiki slovenskega holokavsta. Po naročilu nastala skladba med prvimi obuja spomin na najhujši komunistični zločin proti slovenskemu narodu. Sam naziv skladbe pomeni tudi tu poimenovanje na ravni zvoka, združeno s krščanskim posmrtnim simbolom objokovanja in usmiljenja. Ramovš si je to Pietà zamislil kot mir, tišino roških gozdov (lebdeč zvok oktav v pianissimu) iznad katerih se kot krik dvigne glas tistih, ki so v letu evropske zmage nad nacizmom izgubili življenja v maščevalnem genocidnem dejanju novo prihajajočega totalitarizma (zaostreni disonantni akord $\mathrm{v}$ trobilih fortissimo). Tistih, ki so preživeli strahote tuje okupacije, revolucije in državljanske vojne in ki so nasilno končali v breznih, kjer ležijo še vedno nepokopani. Iz teh roških gozdov in grobišč po vsej Sloveniji se s krikom in

45 Gl. opombo 10. - Razgovor ś skladateljem je potekal še predvsem o vprašanju modernizma in postmodernizma v njegovem ustvarjanju. 
opozorilom dviga njihova tragična usoda in z njo pretresljiva glasba žalovanja in znova spet mir, mir... Pax resurrecturis.

Večja harmoničnost in konkretnost zaradi vsebinske zasnove Ramovševe žalne glasbe torej ne pomenita opustitve modernističnega subjektivizma. Skladatelj zavestno ostaja ustvarjalec modernizma, ${ }^{46} \mathrm{ki} \mathrm{mu}$ predstavlja najvišjo izpovedno vrednoto. V končni posledici gre torej za vprašanje identitete, za moralno vprašanje oblikovanega razmerja do sveta, za vprašanje zvestobe izraznemu načinu in s tem samemu sebi. Sklepamo lahko, da postmodernizem pojmuje kot nekakšno degradacijo, nenačelnost, nepotrebno relativiziranje $z$ več resnicami, pristajanje na neizvirnost, na svojo neidentiteto. Tako ostaja do konca zvest svojemu izraznemu načinu, čeprav sprejema $z$ njim vlogo avantgardista samokritično in zato le delno, ker da ni uvajal novosti v svetovnem merilu, marveč le v svojem okolju v času Enneaphoniae. ${ }^{47}$ A to je moralo pomeniti, da se je izpostavil, prevzel odgovornost, četudi ne nujno več po zgledih zgodovinske avantgarde $\mathrm{z}$ manifesti ali drugimi neumetnostnimi sredstvi. In treba je priznati, da je Ramovš to avantgardno vlogo na Slovenskem, sprejemajoč s tem Osterčevo moralno izročilo iz tridesetih let, prevzel prvi, ko so se mu domala sočasno ali kakšno leto, nekaj let pozneje pridružili mladi skladatelji skupine Pro musica viva. Rečemo lahko, da je bila to upornost in izpostavljenost najbolj kritičnih šestdesetih let, čas odločilnega prodora, ki se je v naslednjem ali naslednjih treh desetletjih iztekal $\mathrm{v}$ izrazit modernizem. Ob tem so prihajali še mladi in mlajši skladatelji, ki so vedno bolj utirali poti novim smerem, predvsem postmodernizmu, ki so skratka gradili na tem, kar so ustvarili starejši. Že izkrčena pot jim pomeni veliko lažje nadaljevanje, lažje tudi zaradi njihovih lažje sprejemljivih estetik. Novo izkrčeni prostor pa se je odprl tudi poslušalcem. Tako je bila slovenski glasbi omogočena "samoumevnost" razvoja in neobremenjen vstop v naslednje tisočletje. Nedvomno še posebno po zaslugi Primoža Ramovša, ki ostaja v naši zavesti s svojo umetniško držo in dosežki eden najpomembnejših skladateljev celotne druge polovice 20. stoletja na Slovenskem in ustvarjalec mednarodnega ugleda.

46 Prim. predhodno opombo.

47 B. Loparnik, op. cit., 191. 


\section{MUZIKOLOŠKI ZBORNIK • MUSICOLOGICAL ANNUAL XXXV}

\section{The Sonorous World of Primož Ramov̌̌ (1921-1999) \\ Summary}

Looking back on the composer's creative journey and work in this year of his death, we are interested in his internal development and, along with this, his artistic identity. His identity took shape in a special relation to sound, that is, its abstraction-from this comes his predominantly instrumental opus and, with it, his fundamental relation to the world.

As a student of Slavko Osterc until the second world war, Ramovš received the spirit of Osterc' avant-garde practices from the thirties and Ramovs was the first to continue these practices during the critical period of the sixties. He, however, identified his mentor as a neoclassical composer even though Osterc was again oriented towards Expressionism from 1934 on; such an orientation was also true of the creative works from Romovš' first period, even still after his studies with Alfredo Casella during the war. This post war neoclassicism was not without influence from socialist realism with its obligatory optimism. This ideological climate most likely caused a slowing down of the composer's development. Such was true during the fifties, when in the course of a long process Ramovs felt the need to redirect himself away from an objective and towards a subjective expression until, with the attained expressionism at the beginning of the sixties, he went through a serial phase including its total organization. His attendance at the "Warsaw Autumn" in 1960 showed him the way forward into the world of aleatory, into a free but controlled improvised form, into free atonality, and into the free use of dodecaphony with "telling" cores of semitone steps. Thus in 1963, he took on the posture of an extreme narrator of subjective modernism, based on continuous contrasts, and characteristic dramatics and upheavals. In this most important third creative period, he continued varying and reconstructing his musical material in more than 400 opuses. His feeling of the world was extremely spiritualized, disharmonic, and based on pure sound, which is the essence of his aesthetics, the indirect expression of a composer's mental and spiritual world. Pure and ascetic sound enabled him a pure musical development, musical narrativity, and later still with a fullness of sound fields. On the mentioned level of sound, he also reacted in a concerned and intense manner; thus, he felt the threat of the extinction of the human race at the coming of the atomic era (Simfonija 68) and he acted as a dedicated nation-conscious composer (in works dedicated to the attainment of Slovenian national independence in 1991 - Per aspera ad astra [1991] or those in remembrance of the victims of the communist holocaust in Slovenia-Simfonija Pietà [1995]).

Ramovs' avant-garde breakthrough in the sixties, when a group of younger composers called Pro musica viva quickly joined him, completes itself in the following three decades in a pronounced modernism, both intensified as well as moderated, which nevertheless do not open the question of postmodernism. With his artistic posture and achievements, he thus remains one of the most important composers of the entire second half of the twentieth century in Slovenia and an artist of international renown. 